\title{
NAmes AND IDENTITY: ABoriginal Canadian TRADITIONS OF NAME-GIVING
}

\author{
Anamaria FăLăUș, Luminița Todea \\ Technical University of Cluj-Napoca, \\ North University Centre of Baia Mare, Romania
}

\begin{abstract}
A name, according to its dictionary definition, is nothing but a word or set of words used to designate a person or thing; it is the term by which someone or something is known, addressed or referred to. The simplicity and naturalness involved in this definition resides in the fact that a name is something that we all share or have in common. The difficulty, yet, arises the moment one has to choose a name, as they are very rarely chosen randomly. If we speak about Christian names, people usually choose them in the hope that some of the chosen saint's attributes might begin to rub off on the newborn baby's life. Giving a child the name belonging to a member of the family would suggest the desire to show gratitude, love and respect towards that person. In comparison with the European tradition of namegiving, First Nations people had neither a Christian name, nor a surname; they had hereditary names, clan names, spirit names, or animal names, just to name a few of them. In view of these things, the purpose of this paper is to take into discussion the First Nations' tradition of name-giving and to analyze its significance in relation to the preservation of one's cultural and ethnic identity.
\end{abstract}

Keywords: name, spirituality, identity, tradition.

\section{Name and naming}

The discussion concerning the issues of name and naming should start from the following questions: "What does it mean to name a thing or a person?", "Is there any significance in the choice of a name?", "Are names just labels that help us distinguish between living and non-living bodies?". In his book What's in a name, Mladen Dolar (2014: 8) begins the debate on this very subject from Plato's dialogue Cratylus (with the subtitle "On the correctness of names"). In the dialogue between Cratylus and Hermogenes that Socrates is invited to mediate, the former believes that names and nature are interconnected, thus acknowledging the existence of a "tie, an umbilical cord that attaches the names to the things named", while the latter claims that names are the result of a convention, a simple agreement among a certain number of speakers. The choice between the arbitrariness of names, on the one hand, and their nature dependence, their deep essence and significance, on the other, has long been the subject of debate and study for psychologists, linguists and philosophers. Generally speaking, naming could be considered the process by 
means of which people classify their environment. But, once again, is this all there is about it?

According to Vygotsky (2012: 87), the moment a child discovers names and attributes them to things represents the turning point at which "speech begins to serve intellect and thoughts begin to be spoken". However, children do not only perceive the things around them; they also have the ability to name them. But words are not simple labels; they possess a meaning that is infused into the objects which they designate (Tschaepe 2003: 75). To name means to "accredit objectivity" and, in addition to it, "self-identity, positivity, plenitude" (Merleau-Ponty 1968: 162). In her book Names and Nunavut: Culture and Identity in the Inuit Homeland, Valerie Alia explores various positions adopted by psychologists, philosophers, linguists and researchers in general in their attempt to define and analyze names. Thus, as far as Gordon Allport is concerned, names are the "focal point" of self-identity organization (qtd. in Alia 2009: 10). Following the same idea, Goethe equals the name with one's self when he calls it a "perfectly fitting garment. It grows over him", the poet continues, "like his very skin. One cannot scrape and scratch at it without injuring the man himself" (Goethe qtd. in Alia 2009: 10). At the opposite end of the continuum, William Dwight Whitney (2013: 135) reduces the importance of names, lowering them to a classification and identification convention: "When a human being is born into the world, custom, founded in convenience, requires that he have a name; and those who are responsible for his existence furnish the required adjunct, according to their individual tastes, which are virtually a reflection of the community in which they live".

However, Valerie Alia (2009: 10) concludes that, irrespective of their position, whether they are mere labels, representations of people, or people, names occupy a central position in defining identity.

Although worldwide there are countless approaches to naming, the act in itself is universal. In the Old Testament, naming stays at the basis of the creation story. God creates the universe and names it, and then creates the man (in His image) and calls him Adam. In his likeness to God, Adam inherits the role of a namer himself, as the one who gives Eve her name. The importance ascribed to the act of naming, which makes the actant part of the creation process, is expressed by Pierre Bourdieu (1991: 105), who says: "There is no social agent who does not aspire (...) to have the power to name and to create the world through naming".

Referring to the various approaches to naming that different cultures might have, Valerie Alia (2009: 13-14) mentions just some of them. According to her findings, in many cultures only a named child is considered alive or human and, due to this belief, he is not named until expected to survive. On the other hand, some cultures stress the necessity of a child being granted a name especially if he/she is expected to die. In this instance, the name becomes a protector and prevents the child from dying soulless. There are also cases that require the renaming of a child. This happens in adoption situations, when the birth name is considered a temporary stopgap: "When a new name cancels the old, the child (or adult) effectively becomes a new person" (Alia 2009: 14). 


\section{Naming and identity}

The process of naming should not be seen as a single, simple performative act, but as a sociocultural approach to identity creation. Identity can be perceived as a "person's process of using action, interaction and creation of images of self and others in order to explore who he or she is or who he or she wants to be in a certain context of the world" (Aldrin 2014: 393). It is definitely not something that rests unchanged, a fixed entity which accepts no alterations. On the contrary, it is a construction, a process never completed. According to Stuart Hall (1996: 4), identities are

never unified and, in late modern times, increasingly fragmented and fractured; never singular but multiply constructed across different, often intersecting and antagonistic, discourses, practices and positions. They are subject to a radical historicization, and are constantly in the process of change and transformation.

Although they seem to be rooted in a historical past from where they extract their energies and potentialities, identities do not simply focus on the idea of being, but on that of becoming (people actually using their resources of history, culture and language in the process of transforming and developing), a person's identity, thus, slowly acquiring new valences and significances in time.

Cultural identities - as they are the ones that we should have in mind in a discussion on naming practices - follow the same pattern. As far as Hall (1990) is concerned, there are two ways of interpretation and analysis that can be applied to cultural identities. The first position sees them as "a sort of collective 'one true self' $(. .$.$) which$ people with a shared history and ancestry hold in common", reflecting "the common historical experiences and shared cultural codes which provide us, as 'one people', with stable, unchanging and continuous frames of reference and meanings" (Hall 1990: 223). The second one, however, interprets cultural identities as "a matter of 'becoming' as well as of 'being' " (Hall 1990: 225), which means they are rooted in the past, but have undergone continuous transformations and alterations in time: "Far from being eternally fixed in some essentialised past, they are subject to the continuous 'play' of history, culture and power" (Hall 1990: 225). As part of a people's cultural heritage, naming practices contribute to the creation and profile delimitation of different cultural groups. Along with other norms, values, beliefs, symbols, and practices, they sketch out the portrait of a community. Their continuity in time, irrespective of various inherent alterations, means cultural identity preservation.

\section{Aboriginal peoples of Canada}

Present day Canada has benefited from the contributions of many cultures. In addition to the ones that came from other places, such as Europe or Asia, there were also the ones that belonged to that very place, namely those of the Aboriginal peoples, or better called the founding peoples of Canada. Diversity has always played a role in Canada's past, beginning with the many Indigenous peoples that form part of Canadian 
society today. "Aboriginal peoples" is an umbrella name that includes First Nations ${ }^{1}$, Métis and Inuit peoples. The Constitution refers to First Nations as "Indians", in order to preserve the name used at the time of negotiating Treaties ${ }^{2}$. Europeans used the word Indian to describe the First Nations of North America, although these people were diverse and had their own names.

Among the stereotypes used in relation to the concept of American Indians, one can mention the idea that Indians are all alike. The reality, however, contradicts this misconception. According to Devon Mihesuah (1996: 20), in America alone there are 511 culturally distinct federally recognized tribes and approximately 200 unrecognized ones, these historic tribes differing greatly in terms of religious beliefs and practices, language, dress and hairstyle, psychology, political and social organization and structures, world views and living conditions dependent on the environment they inhabited (forests, deserts, mountains, plains and coasts, subarctic and arctic areas).

Another stereotype refers to the wrongly acknowledged conception that Indians had no civilization until Europeans brought it to them (Mihesuah 1996: 37). Ethnocentrism is the concept that best exemplifies the tendency to see and judge others through the eyes of your own culture and to consider them inferior. From this perspective, Europeans generally proffered negative evaluations of other societies, considering them "uncivilized", "primitive" and even "barbarian", due to the fact that the latter's thought systems and social organizations differed substantially from their own. As a result of this presumption, upon encountering Indians, Europeans came with a tripartite solution: some attempted to help them progress and consequently proceeded to assimilate them into Euro-American society by converting them to Christianity and transforming them into farmers; others preferred to see them die out in the face of white advancement, while others considered reservations the best solution, where the Indians could survive without "hindering white progress" (Mihesuah 1996: 39). In Canada's case, the Indian Act of 1876 was such an attempt to assimilate people of the First Nations. At points in its history, this act defined how First Nations had to conduct their affairs, such as organizing band elections, although they had their own ways of governing themselves, restricted the rights of these people to travel freely, to take political action, to wear traditional clothes, and to take part in traditional ceremonies (for example, the Sundance of Siksika was altogether banned). Until 1960, the act required

\footnotetext{
1 A term that came into common usage in the 1970s and can refer to the Indian peoples of Canada, both status (registered with the federal government according to the terms of the Indian Act of 1876) and non-status (those not registered), but does not include the Métis or the Inuit (Dyck 2009: 72).

2 The Numbered Treaties are historic agreements that affect the rights and identity of some First Nations in Canada. They have roots in the Royal Proclamation of 1763, which was made by Britain at the end of the Seven Years' War with France in order to establish control over land in North America formerly claimed by France. The proclamation recognized First Nations' rights to land and established the principle of making treaties with First Nations through peaceful negotiation (Lychak et al. 2008: 124).
} 
First Nations people to give up their legal identity and Treaty rights to gain the right to vote (Lychak et al. 2008: 100, 137). Another method that promoted the same discrimination and injustice was the experiment of the residential schools, where until the 1970s many Aboriginal children were forced to go, only to be punished for speaking their Aboriginal language or engaging in Aboriginal customs (Dyck 2009: 74). These prohibitions and censures on spiritual practices, cultural traditions, rituals and language brought about considerable damage to the society of First Nations people, having negative impacts on their identity preservation. The native naming practices have managed to remain a defining element of these people's culture although they were banned or outlawed in some cases, treated as pagan, devoid of any sacredness, and granted only the value of ritualistic dances.

Despite the changes that history has brought about in time to counterbalance the drawbacks of the process of integration to which the Aboriginal peoples of Canada were subjected, distorted images of Indian culture are still all-pervasive nowadays, ranging from "the extremely pejorative to the artificially idealistic, from historic depictions of Indians as uncivilized primal men and winsome women belonging to a savage culture, to present day Indians as mystical environmentalists, or uneducated, alcoholic bingo-players confined to reservations" (Mihesuah 1996: 9). In spite of all these negative images and irrespective of their diversity in terms of beliefs, practices, and traditions, there is one thing these Aboriginal peoples have in common, and this is a holistic approach to understanding life and the surrounding world (Juchnowicz 2008: 280). This means that whatever happens in nature reverberates in people's lives, the natural world and the spiritual one being interconnected. Aboriginal Canadians believed that the world around them was governed by "a panoply of spirits" (Ray 2016: 31). Accordingly, they constantly tried to attract and preserve the good will and help of these supernatural powers by showing them respect through various public and private ritual practices. Spirituality embraces all aspects of these people's lives. If for the Western culture religion seems to be related to the unreal, the "Otherworld", this point being reached only upon death or through the mediation of a priest, for Native American tribes religious experiences seem to be ubiquitous, surrounding man all the time. In their case "there is probably nothing that can be called nonreligious" (Toelken 1976: 11). In order to avoid negative stereotyping and bias, in order to get rid of the duality us (civilized, culturally and socially advanced) - them (barbarians, savages), in order to properly understand Indian patterns of perception, ceremonies, and sensitivity to nature, we should try to see and interpret everything with a native eye. As Barre Toelken (1976: 12) says, "if we talk about native American religions using the categories of Western religions, we are simply going to see what we already know is there". Things can easily be misinterpreted as the perception might be different. If for us a dance may be an art form or a certain kind of kinesis, for certain Aboriginal people dance may be the most religious act someone can perform. 


\section{Aboriginal Canadian name-giving traditions}

In Aboriginal cultures, the naming of children had spiritual significance. In her book Names and Nunavut: Culture and Identity in the Inuit Homeland, Valerie Alia (2009: 17) speaks about the Inuit tradition of name-giving, considering it "the deepest and most intricate naming system in the world". According to her point of view, names are "the heart and soul of Inuit culture" (Alia 2009: 17), the Inuit naming system being a multilayered one, based on what they call sauniq - a powerful form of namesake that is described as a kind of reincarnation. After being named, the child becomes the sauniq or the 'bone' of all those who have shared that name. The name links people in complex and intricate ways, connecting their souls to cosmic forces. This leads to the conclusion advanced by Robert Williamson, who considers the Inuit idea of a compound, multilayered soul and the related naming system far more complex than the idea of soul that has been "conceptualised by more modern religious beliefs such as Christianity (...). The name, in Eskimo belief, is the soul, and the soul is the name" (qtd. in Alia 2009: 19). This tradition follows the idea that a personal name equates the soul of an individual. By passing on the name to a newborn, the life and memory of an individual is able to continue beyond death: "Since names were thought to carry life, naming a child after a deceased family member was a way of bringing that person back to the community" (Filice 2015). Names thus become a heritage project.

First written in 1978 by Mini Aodla Freeman, Life among the Qallunaat is the account of an Eskimo woman's adaptation to the southern way of life, after a traditional upbringing in the North. This is how she recalls the naming traditions of her childhood:

Before I was born my mother had to decide who would be involved at my birth (...). The first person who has to be there is a mid-wife, man or woman. In my case it was my grandmother ( ... ). Also present at my birth was the person I was named after, my other grandmother. This automatically meant that I would never call her 'grandmother' nor would she call me 'grandchild'. Instead we called each other sauniq, namestake, bone-tobone relation (...). Our belief is that no one really dies until someone is named after the dead person. So, to leave the dead in peace and to prevent their spirits from being scattered all over the community, we give their names to the newborn. The minds of the people do not rest until the dead have been renamed (Freeman 2015: 72, 50).

Valerie Alia continues her research by noting down the difficulties that might appear in the process of choosing a name. According to her findings, a baby will be renamed until he or she seems healthier, stops crying or seems calmer. Different names are tried until the difficulties cease and the birth takes place (Alia 2009: 18).

Michelle Filice (2015) speaks about the complexities that used to characterize the process of naming a child in the Inuit culture before the European arrival. According to her point of view, the ritual was meant to reflect the essential elements of their culture, namely the environment, animals, family, and spirits. The naming ritual was consequently thought to be an epiphany through which the child was "discovered", 
i.e. his connections to the past were revealed and his future destiny was in some way foreseen. Elders were the ones to be asked for advice in choosing names. There were also situations in which the future mothers had visions or dreams in which the names appeared. The simple gesture of a newborn could bring about memories of a deceased family member, and the latter would become the child's namesake.

In her book The Power of Names: Uncovering the Mystery of What We Are Called, Mavis Himes registers the confession of her friend Anne, a member of the Anishnaabe, who agreed to speak about names and naming practices among First Nations. Her story goes like this:

"My family name is Bigwin, an Anglicized name, and likely a modified translation of Bigwind, which would have been che (big) and nodin (wind) in Ojibway. Someone must have thought Bigwind sounded funny and so they dropped the $d$. One family member is married to a man whose surname is Starblanket, a direct translation from Cree. My Ojibway brother-in-law, a man who grew up on a reserve, has the surname Jamieson. And my husband's surname is Meawasige, an Ojibway word that means 'beautiful light'. So there you go: Bigwin, Starblanket, Jamieson, Meawasige. Four names, four different manifestations of naming. We are all First Nations and our names tell the story of my people in Canada, the First Nation experience in this country - the modification, the English translation, the English name, and the First Nation name without change or translation. I find it incredible that this phenomenon is represented in one family" (qtd. in Himes 2016: 65).

When asked to speak about naming ceremonies, she agreed, not without mentioning the fact that she could only speak for the Ojibway people, "her people, who were part of the Anishinaabeg, known as the woodland people and identified by the Algonquin linguistic group" (Himes 2016: 66). Her confession seems to be a testimony in favor of the multitude of naming rituals existing among the Aboriginal people:

"When a parent or parents want to give their name to a child, they approach the Medicine People to give them an Indian name. The child may already have a Canadian name, but the Indian name is to be used at the person's discretion and always with outmost respect. Again, due to generational breakdown, today an Elder would be approached for this task. The Indian name would always come through a vision, a dream or, through the spirit of the person to be named. It would never be a random selection or a request by the parents, and it would always contain a reference to nature in respect of the importance of interconnectedness and balance in nature.

The naming ceremony is very elaborate, with very explicit rituals that must be observed. First a fire is lit, as smoke connects Mother Earth with the Creator. The tobacco, considered a sacred plant used in all traditional rituals, would be first offered to the Elder who is conducting the ceremony and a prayer on the name would be said. The person to be named would then be walked around the feast by the Elder, who would be talking to him at the same time. This walk-around signifies the circle of life. Then he would be taken outside for the sunrise ceremony and the Elder would lift him up in the four directions - north, south, east, west - four being significant in terms of the four directions, the four 
winds, the four seasons. At that point, he would be given his name, and more tobacco would be put on the fire. There would then be an elaborate feast with traditional food that would take all night to prepare. The feast would then be consumed and the occasion celebrated with great joy and happiness.

My son's name, which was given to him at three months, was the name of his paternal great grandfather, and actually the name of the father of the Elder performing the ritual. This name is Meshkeegwun" (qtd. in Himes 2016: 66).

Analysing oral traditions in contemporary narrative writing, and taking into discussion Ruby Slipperjack's books Silent Words and Honour the Sun, Katarzyna Juchnowicz speaks about native people's names, their powers and the stories that lie behind them. The strong relationship between names and nature is exemplified in the story narrated by the Owl, one of the characters of the book Honour the Sun, written in 1987. As far as the narrator recalls, "an owl hooted several nights in a row outside our cabin before I was born. My brother threatened to go out and shoot it because it kept everyone awake. It went away when I was born but I was a night baby with big round eyes and I made such an awful noise crying all night long, that no one in the cabin could get any sleep (...). I don't think my brother was too happy about me, either!" (qtd. in Juchnowicz 2008: 281).

In comparison with the above-mentioned practices, Métis ancestry is a symbiosis between the resident population and the Europeans, a union of two cultural heritages, Aboriginal and European. Consequently, their stories are layered, beginning with the traditions of the native people, continuing with the story of the fur trade's expansion into North America, and adding layers and layers of influences and connections. Along with Heather Devine, Brenda Macdougall (2010: 77) argues that Métis naming practices were an amalgam of French Catholic and First Nation spiritual customs. Due to their mixed ancestry, they adopted both traditions. Roman Catholic doctrine required parents to select their children's names from the names of the saints mentioned in the Bible. On the other hand, the Dene and Cree practice was based on the presence of elders endowed with certain spiritual abilities. They were given offerings of tobacco and cloth and asked to pray for an appropriate name. Both traditions were expected to grant the child with spiritual protection. If the European tradition was somehow considered unimaginative, the parents having just a limited pool of names to choose from, the native ritual was rooted in nature and consequently treated as profane. However, both practices had their own role. By conferring familial first names on children, the European side attempted to "symbolically maintain the ancestral ties to French or British relatives in eastern Canada or Europe" (Macdougall 2010: 77), while the aboriginal ritual was meant to "establish an ancestral memory of a people and a place that most north-western Saskatchewan Métis would never see or experience" (Macdougall 2010: 77). 


\section{Conclusion}

All these examples have demonstrated the diversity of the practices employed by Aboriginal peoples in their naming rituals and consequently, their rich cultural heritage. However, when an ethnic group or nation falls under the control of a more powerful and expanding group, its members may be forced to assimilate and give up their cultural identity. This is exactly what happened to American Indian families who came under pressure to forgo their cultural traditions, including their customary personal and family names. As part of the assimilation process, many agreed or were compelled to have their indigenous names translated into English (Haviland et al. 2013: 130). Today, Aboriginal people use a mixture of Euro-Canadian and traditional native names. Although paved with good intentions, the government's repeated attempts and initiatives to simplify and streamline things (for example, The Project Surname was based on the federal government's decision to better identify the Inuit for the administration of its programs and to compile census data - see Filice 2015$)^{3}$ led to the alteration of both Aboriginal naming traditions and their relationships with the state.

The purpose of this paper was to take into discussion Aboriginal Canadian traditions of name-giving and to analyze their significance in relation to the preservation of one's cultural, ethnic identity. Although different from the European tradition of giving names, native peoples' practices could not and should not be considered lower in rank and significance. If, from a European perspective, native names and naming practices are considered profane, secular, the point of view changes if we reverse the angle of analysis. Interpreted in themselves, without reference to any other culture, their sacredness cannot be denied. As we have already mentioned, in order to understand these peoples' traditions and rituals we have to see and perceive them through the "eyes of a native". Any attempt to hinder their full manifestation could be interpreted as an attempt to deny their identity and contribution to the shaping of present-day Canadian society.

\section{References}

Aldrin, E. 2014. Choosing a Name = Choosing Identity ? Towards a Theoretical Framework. In Names in Daily Life: Proceedings of the XXIV ICOS International Congress of Onomastic Sciences, Joan Tort i Donada and Montserrat Montagut i Montagut (eds.), 392-401. Barcelona: Generalitat de Catalunya. http://www.gencat.cat/llengua/BTPL/ICOS2011/044.pdf (accessed August 27, 2017).

Alia, V. 2009. Names and Nunavut: Culture and Identity in the Inuit Homeland. New York: Berghahn Books.

3 In the Inuit case, names were unique and consequently did not recognize shared family names or surnames. Women did not take their husbands' family names and, moreover, names were not gender specific: "It was believed that people with the same name were essentially one person, whether male or female. From generation to generation, Inuit namesake traditions served to bound families and communities, simultaneously ensuring the survival of Inuit culture" (Filice 2015). 
Bourdieu, P. 1991. Language and Symbolic Power. Cambridge: Harvard University Press.

Dolar, M. 2014. What's in a Name? Ljubljana: Aksioma.

Dyck, R. 2009. Canadian Politics. Concise fourth edition. Toronto: Nelson Education Ltd.

Filice, M. 2015. Project Surname. In The Canadian Encyclopedia. http://www.thecanadianencyclopedia.ca /en/article/project-surname/ (accessed August 27, 2017).

Freeman, M. A. 2015. Life among the Qallunaat. Manitoba: University of Manitoba Press.

Hall, S. 1990. Cultural Identity and Diaspora. In Identity: Community, Culture, Difference, J. Rutherford (ed.), 222-237. London: Lawrence \& Wishart.

Hall, S. 1996. Introduction: Who Needs 'Identity'? In Questions of Cultural Identity, S. Hall and P. Du Gay (eds.), 1-17. London: SAGE Publications.

Haviland, W. A., H. E. L. Prins, B. McBride and D. Walrath. 2013. Cultural Anthropology: The Human Challenge. $14^{\text {th }}$ edition. Wadsworth: Cengage Learning.

Himes, M. 2016. The Power of Names: Uncovering the Mystery of What We Are Called. Maryland: Rowman \& Littlefield.

Juchnowicz, K. 2008. Reflections of Oral Traditions in Contemporary Native Writing: Ruby Slipperjack's Honour the Sun. In Aboriginal Canada Revisited, K. Knopf (ed.), 270-289. Ottawa: University of Ottawa Press.

Lychak, P., D.A. Gerrits, A. Nogue and J. Parsons. 2008. Issues for Canadian. Toronto: Nelson Education Ltd.

Macdougall, B. 2010. One of the Family. Metis Culture in Nineteenth-Century Northwestern Saskatchewan. Vancouver: UBC Press.

Merleau-Ponty, M. 1968. The Visible and the Invisible. Evanston: Northwestern University Press.

Mihesuah, D. A. 1996. American Indians: Stereotypes \& Realities. Atlanta: Clarity Press.

Ray, A. J. 2016. An Illustrated History of Canada's Native People: I Have Lived Here Since the World Began. $4^{\text {th }}$ edition. Quebec: McGill-Queen's University Press.

Toelken, B. 1976. Seeing with a Native Eye: How Many Sheep Will It Hold? In Seeing with a Native Eye: Essays on Native American Religion, W. H. Capps (ed.), 9-24. New York: Harper \& Row.

Tschaepe, M. D. 2003. Halo of Identity: The Significance of First Name and Naming. In Janus Head 6 (1): 67-78. Pittsburgh: Trivium publications.

Vygotsky, L. 2012. Thought and Language. Cambridge: MIT Press.

Whitney, W. D. 2013. The Life and Growth of Language. Cambridge: Cambridge University Press. 